\title{
Think-Pair-Share, Co Op-Co Op and Traditional Learning Strategies on Undergraduate Academic Performance
}

\author{
Marwan Zaid Bataineh \\ Department of Psychology, College of Education, King Saud University, P.O. BOX 2458, Riyadh 11451, Saudi Arabia \\ Email: marwanksu@yahoo.com
}

Doi:10.5901/jesr.2015.v5n1p217

\begin{abstract}
The study aimed to investigate the effect of using think-pair-share, co op- co op and traditional learning strategies on undergraduate students' academic performance in educational psychology course. The convenience sample used consisted (70) undergraduate students' who study the educational psychology course, from faculty of education at King Saud University. This study employed a quasi-experimental - nonequivalent control-group design with pretest, posttest and delayed posttest. In this study, educational psychology performance test (EPPT) was used to measure the students' performance. The test consisted of 30 multiple choice questions to collect the relevant data. The data collected was analyzed using descriptive, oneway ANOVA, independent samples t-test statistical methods. Findings of this study revealed that: There was no significant difference in the pretest academic performance mean scores between students. There was significant difference in the posttest academic performance mean scores between the experimental groups (Co Op-Co Op), (Think-Pair-Share) and control group (traditional method). There was significant difference in the posttest academic performance mean scores of second and fourth year students after the intervention with favor for the second year students. There was no significant difference in the posttest academic performance mean scores between students from different specialization (psychology, special education, and islamic studies). There was significant difference between experimental group (Co Op-Co Op) and control group (traditional method) on the delayed posttest mean difference and significant difference between experimental group (Think-Pair-Share) and control group (traditional method). There was no difference in academic performance between the experimental groups (Co Op-Co Op) and (Think-Pair-Share) in the posttest and delayed posttest.
\end{abstract}

Keywords: Think-Pair-Share, Co Op-Co Op, Traditional method, Academic Performance, Level of study, Specialization, Undergraduate Students'.

\section{Introduction}

Students' of higher learning institutions are required to possess the necessary skills for knowledge achievement and required to adapt meta-cognitive strategies in order to continue their studies by setting high learning targets as they come across differnt kinds of examination questions and tasks. Paulsen and Faust (2008) note that there is still a hesitation and resistance in higher education to modify traditional college classes into cooperative learning environments. In spite of the pedagogical benefits, under the wrong concepts that cooperative learning is an alternative to, rather than an enhancement of professorial lectures, many avoid integrating cooperative learning into their classes. However, Weimer (2007) when asked about the teaching methods they most commonly employ, $76 \%$ of college professors reported that lecture was their "primary approach" to teaching. Even though many may dabble into the field of cooperative learning as indicated by Fink (2004), it is not common practice. Due to the expert nature of higher education, much evidence suggests that many college professors still cling to the notion of expounding knowledge to their students rather than engaging them in discovering such knowledge through active learning (Ediger, 2001; Murry \& Murry, 1992; Felder, 1992).

Johnson, Johnson, and Smith (1998) assert that cooperative learning is suitable for college students. They found that students must learn to cooperate because today's students traditionally come from a background where cooperation within the family unit is not as important for survival as it once was. The corporate world values cooperation, hence cooperative learning is a valuable learning structure.

Therefore, the problem in many universities is that many instructor's still continue to teach with traditional methods of instruction (lecture and note taking) in which the instructor is provide factual information, test students, and assign grades instead of using methods in which active learning place and meet the students needs. However, The purpose of this quantitative study was to compare the effects of cooperative teaching and learning strategies (Co Op-Co Op and Think-Pair-Share) with traditional teaching strategy used by instructor's on undergraduate students' academic 
performance in the faculty of education at King Saud University. The researcher attempted to determine the effects of three different teaching strategies on undergraduate students' academic performance in educational psychology course.

Based on the above matter the researcher addressed the following specific hypothesis, which will guide the present research.

\subsection{Research Hypothesis}

H01: There is no significant difference in the pretest academic performance mean scores of students in educational psychology course.

H02: There is no significant difference in the posttest academic performance in educational psychology course between the experimental groups ( $\mathrm{Co} \mathrm{Cp}$-Co Cp), (Think-Pair- Share) and the control group (tratidional strategy).

H03: There is no significant difference in the posttest academic performance mean scores of students from different level of study (second and fourth year).

H04: There is no significant difference in the posttest academic performance mean scores of students from different specialization (psychology, special education, and Islamic studies).

H05: There is no significant difference in the delayed posttest academic performance mean scores of students in educational psychology course.

\subsection{Research objectives}

To determine if there are difference in educational psychology performance among students taught through cooperative learning strategies (Co Cp-Co Cp), (Think-Pair- Share) and traditional teaching strategy. However, the researcher attempted to determine the effects of three different teaching strategies on students' academic performance, to support the previous studies about the fact of using cooperative learning can raise student performance while enhancing higherorder thinking abilities and problem-solving skills (Daniels \& Perry, 2003; Palincsar \& Herrenkol, 2002; Slavin, 1996).

This study gives insight into which methods of cooperative learning are most effective in promotes cognitive, social development of students' and preparing learners to become higher-order thinkers .

This study insiprt the instructors who are hesitate to use cooperative learning strategies to implement these strategies in their daily teaching.

In addition to cooperative learning promoting social skills,enhances personal competencies, and help students to evaluate their own strengths and weaknesses of each others.

\section{Theoritical Background}

The theoretical foundations of cooperative learning grew out of the work of social psychologist, Morton Deutsch, who specialized in the study of social interdependence (Kimberly et al., 2003). Deutsch studied the effects of different group structures on the process and outcomes of group efforts in a variety of social and work settings. There are two major theoretical perspectives related to cooperative learning-motivation and cognitive (Rossini and Jim, 1997). The motivational theories of cooperative learning emphasize the students' incentives to do academic work, while the cognitive theories emphasize the effects of working together. There are two cognitive theories that are directly applied to cooperative learning, the developmental and the elaboration theories (Slavin, 1987). The developmental theories assume that interaction among students around appropriate tasks increases their mastery of critical concepts (Damon, 1984). When students interact with other students, they have to explain and discuss each other's perspectives, which lead to greater understanding of the material to be learned. The struggle to resolve potential conflicts during collaborative activity results in the development of higher levels of understanding (Slavin, 1990). The elaboration theory suggests that one of the most effective means of learning is to explain the material to someone else. Cooperative learning activities enhance elaborative thinking and more frequent giving and receiving of explanations, which has the potential to increase depth of understanding, the quality of reasoning, and the accuracy of long term retention (Johnson et al., 1986).

Learning together strategy of cooperative learning was originally developed by David Johnson and Roger Johnson at the University of Minnesota. Students work in four or five heterogeneous groups on a group assignment sheet. During discussion, if students ask the teacher a question, the teacher will refer such students to their groups to find answer. After the group discussion, a leader is chosen to present group's result to the entire class, and groups receive reward together. Scores are based on both individual performance and the success of the group, but individual do not compete 
with one another. The learning together strategy of cooperative learning provides a conceptual framework for teacher to plan and tailor cooperative learning strategy according to their circumstances, students' needs, and school contexts (Ghazi, 2003).

In the present study the researcher addressed two models of cooperative learning developed by Kagan.

\subsection{Think-Pair - Share}

Informal learning strategies introduced by (Kagan, 1989) where students think of an answer to a question, share their answer with a partner, and then that pair shares with another pair. Finally the foursome creates an answer that represents the consensus of the their group to the whole class. This activity may take fewer than 15 minutes. Ransdell used this strategy with her graduate class. After discussing the terms "reflective" and "practitioner," students individually, created a definition for a "reflective practitioner." Each student shared his or her definition with a partner. The partners shared their definitions with another pair. Then the foursome created a definition to share with the whole class.

\section{$2.2 \mathrm{CoOp}-\mathrm{CoOp}$}

Formal cooperative learning strategy is Co Op-Co Op. This strategy was created for the college classroom (Kagan, 1985). Groups of students become experts in a particular aspect of a topic. The students take either their own time, or class time to research, discuss, and learn the material. They create a presentation for their classmates to teach the assigned aspect of the topic to their classmates. The professor has a right to include additional information or clarify at the end of the presentation. All students in the class will be held accountable for key information given in the presentations. In addition too, instructor evaluate a written product for each mini-topic, team members evaluate one another for contributions to the team, and the class evaluates the team presentations.

\subsection{Cooperative Learning and Academic Achievement}

Christian and Pepple (2012) investigated the effects of cooperative and individualized learning strategies on students' achievement in chemistry in Rivers State. Three hundred and seventy, 370 Senior Secondary II students drawn from six public secondary schools constituted the sample of this study. The $3 \times 2 \times 2$ factorial pretest-posttest quasi-experimental and control design was adopted for this study. The topic of instruction was thermochemistry. Two research questions and two research hypotheses were posed for the study. Three instructional materials, cooperative learning workbook, CLW, branching programmed text, BPT and conventional lesson note, CLN were used for intervention and a 35-item multiple choice chemistry achievement test, CAT was used for data collection. Mean, standard deviation, linear regression, ANCOVA and Scheffe Multiple Comparisons were used for data analysis. The results show statistically significant effect of learning strategies on students' achievement in chemistry with the following trend: conventional individualized cooperative. The result also shows a very weak and significant effect of the combination of all the predictor variables on students' achievement. However, relatively the effect of the individual predictor variables on students' achievement in chemistry was found to describe the following trend: age<gender<learning strategies with learning strategies and gender having significant relative effect students' achievement.

Study by Oludipe (2012) investigated the influence of gender on Junior Secondary students' academic achievement in basic science using cooperative learning teaching strategy. Total number of one hundred and twenty (120) students obtained from the intact classes of the three selected Junior Secondary Schools in the three selected Local Government Areas of Ogun State, South-west Nigeria, participated in the study. This study employed a quasiexperimental design. Lesson note based on the jigsaw II cooperative learning strategy and Achievement Test for Basic Science Students (ATBSS) were the instruments used to collect the relevant data. The data collected was analyzed using descriptive and independent samples t-test statistical methods. Findings of this study revealed that there was no significant difference in academic achievement of male and female students at the pretest, posttest, and delayed posttest levels respectively.

Sahin's (2010) experiment to uncover whether the Jigsaw II method would yield higher posttest and retention scores in Turkish preservice teachers found that the experimental group of Jigsaw II subjects $(n=42)$ had higher posttest scores than the control group $(n=38)$ that learned the material through traditional teacher-centered instruction. However, findings suggest that Jigsaw II is more effective for learning and retention than traditional teacher-centered instruction.

Hwang et al. (2005) studied the effect of collaborative teaching versus lectures including the type of questions 
posed to students (i.e. indirect and direct application of the acquired knowledge). This study concludes that cooperative teaching improves significantly the students' performance in comparison with that of lectures, only. Despite all the evidence, that collaborative teaching has better results than the traditional way of lecturing, there is no compelling evidence in support of one method over the other.

Gocer (2010) conducted a comparative pre- and posttest study on Turkish high school students' ability to learn literary genres through cooperative (Jigsaw) and individualistic settings. The students in the group using the Jigsaw method showed significantly greater improvement between pre- and posttest scores than the control group.

Queen (2009) conducted a quasi-experimental study examined the effects of cooperative learning verses traditional teaching strategies on the academic performance of 216 6th grade language arts students in north central Georgia. The convenience sample was divided into a control group that was instructed using traditional strategies; and a treatment group that was instructed using cooperative learning strategies. Pre and posttest scores from a standardized 73-item language arts benchmark test was used to assess the overall impact of instructional techniques across student use of conventions, literary elements, sentence structure, context clues, and vocabulary. ANOVA results indicated that the cooperative learning group made significantly greater gains than were observed for the traditional instruction group.

\section{Methodology}

An experimental quantitative method was chosen in which two group received an intervention, while the other group did not. Creswell (2003) reported that, "The basic intent of an experiment is to test the impact of a treatment (or an intervention) on an outcome, controlling for all other factors that might control that outcome". The non equivalent control group design used in the study were its one of the most quasi-experimental designs used in educational research, humanities and social. Jackson (2011) reported that the pretest allows us to assess whether the groups are equivalent on the dependent measure before the treatment given to the experimental group. In addition, such design assess any changes that may have accurred in either group after treatment by comparing the pretest measure for each group with their posttest measure and compare the performance of the two groups on both pretest and posttest measure. Also can compare performance within each group from the pretest to the posttest.

\subsection{Research Design}

The research was carried out using a quasi-experimental design with pretest, posttests and delayed posttest with two experimental groups and one control group from faculty of education at King Saud University. Convenience sampling was used. This sampling procedure allowed the participants in the study to be chosen based on availability. The rationale for selecting convenience sampling was the availability of naturally formed groups (Creswell, 2003). The sample consisted of (70) male undergraduate students from three classes, who study the educational psychology course in second semester 2014-2015. The researcher selected the nonequivalent control-group design with pretest, posttest and delyead posttest. Creswell stated that with this design, random sampling does not occur and pre- and posttests are administered to the study groups, but only the experimental groups receives the treatment. One group of students was

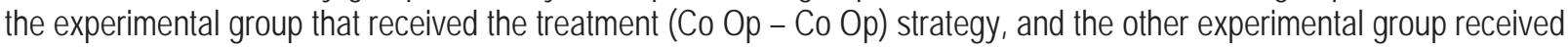
the treatment (Think-Pair-Share) strategy. The control group was instructed with traditional teaching methods. A pretest was administered and test scores were gathered. Then, the units was taught to the study groups. At the conclusion of the unit, a posttest and delayed posttest were administered by the instructor and data was collected.

\subsection{Procedures}

1- At the beginning of the study, the instructor administered a pretest in educational psychology course in (classical conditioning and operant conditioning) for the three groups .

2- Then, the instructor spent time teaching the first experimental group about using the Co Op - Co Op strategy (three hours lecture), and teaching the second experimental group about using Think - Pair - Share strategy (three hours lecture). whereas the control group received traditional methods of instruction.

3- However, treatment groups were selected intentionaly and instructed through cooperative learning strategies for six weeks.

- First experimental group using (Co Op - Co Op): instructor divided the students into five groups, every group consist of five student's and provide them with the instructions about the topic and subtopic they 
have to study, research and gathring the data related to their presentation (one week preperation). However, the group students become experts in the topic aspects and they teach the assigned aspects of the topic to their classmates.

- Second experimental group using (Think- Pair - Share): instructor begin by asking a specific higher-level question about the topic, students will be discussing. Students "think" about what they know or have learned about the topic for a given amount of time (2 - 5 minutes).

- Pair: Each student should be paired with another student. Instructor let students pick their own partner. Students share their thinking with their partner, discuss ideas, and ask questions of their partner about their thoughts on the topic (2-5 minutes).

- Share: The partners shared their definitions with another pair (foursome) and have a discussion for (2 - 5 minutes), instructor allow each group to choose who will present their thoughts, ideas, and questions they had to the rest of the class. Instructor expand the "share" into a whole-class discussion.

4- Three days after the completion of treatment, the instructor administered a posttest measured academic performance reflect the units taught (classical conditioning and operant conditioning) for the three study groups at the same time. The posttest is the same 30 items - mutliple choice test that was used for the pretest

5- The researcher, compared test scores of the control group and the two experimental groups and determined statistically whether one group achieved significantly better scores than the others.

6- delayed posttest was administerd one week after, to measure the delayed remembering of the students'.

\subsection{Instruments}

In this study, educational psychology performance test (EPPT) was used to measure the students' performance. The test consisted of 30 multiple choice questions with three options and only one correct answer. The performance test was constructed based on the text book used to tough the course.

\subsection{Validity}

The instrument (EPPT) were validated by content and face-to-face validity methods. For validity, the instruments were revised with the suggestions of the experts in the field from the faculty of education at King Saud University. However, the items of the test were adjusted and evaluated according to the experts comments.

\subsection{Reliability}

Reliability was found using Kunder -Richardson 21 for the sample of (40) students differe from the study sample. The 0.74 was found to be reliable based on McMillan and Schumacher (2006) criterion of a minimum of 0.70 . $\mathrm{KR}_{21}=[\mathrm{n} /(\mathrm{n}-1)] \times\left[1-\left(\bar{X} \times(\mathrm{n}-\bar{X}) /\left(\mathrm{n} \times \mathrm{S}^{2}\right)\right)\right]$

Table 1: Reliability for (EPPT) using Kunder - Richardson 21

\begin{tabular}{|l|c|c|c|}
\hline Tests & Reliability & Test items & options \\
\hline Educational psychology performance Test (EPPT) & 0.74 & 30 & 3 \\
\hline
\end{tabular}

\subsection{Data Analysis}

Pretest, posttest and delyead posttest data analysis was conducted with the use of descriptive, one way ANOVA, and independent sample t-test. This analysis was used to determine whether significant differences in students' performance occurred. 


\section{Result}

Table 2: Descriptive Statistics of the Sample

\begin{tabular}{|c|c|c|}
\hline Groups & N & $\%$ \\
\hline Co Op-Co Op & 25 & 35.7 \\
Think- Pair-Share & 16 & 22.9 \\
Control & 29 & 41.4 \\
Total & 70 & 100.0 \\
\hline Specialization & & \\
\hline Psychology & 30 & 42.9 \\
Special Education & 25 & 35.7 \\
Islamic Studies & 15 & 21.4 \\
Total & 70 & 100.0 \\
\hline Level of the Study & & \\
\hline Sconed Year & 40 & 57.1 \\
Fourth Year & 30 & 42.9 \\
Total & 70 & 100.0 \\
\hline
\end{tabular}

H01: There is no significant difference in the pretest academic performance mean scores of students in educational psychology course.

To answer hypothesis 1 the researcher used ANOVA to find the differences between students performance in the pretest.

Table 3: Pretest academic performance by ANOVA

\begin{tabular}{|c|c|c|c|c|c|}
\hline & Sum of Squares & $\mathrm{df}$ & Mean Square & $\mathrm{F}$ & Sig \\
\hline Btween Groups & 7.893 & 2 & 3.946 & & \\
Within Groups & 312.679 & 67 & 4.667 & .846 & .434 \\
Total & 320.571 & 69 & 4.671 \\
\hline
\end{tabular}

Table 3 indicate that there was no significant difference $(F=.846, P=.434)$ in the pretest academic performance mean scores between students. By this finding the null hypothesis was accepted.

H02: There is no significant difference in the posttest academic performance in educational psychology course between the experimental groups (Co $\mathrm{Cp}-\mathrm{Co}_{0} \mathrm{Cp}$ ), (Think-Pair- Share) and the control group (tratidional strategy).

To answer hypothesis 2 the researcher used one way ANOVA for the posttest and scheffe test to find the difference between the experimental groups and control group as shown in table (4and 5).

Table 4: posttest academic performance between experimental groups and control group by ANOVA

\begin{tabular}{|c|c|c|c|c|c|}
\hline & Sum of Squares & $\mathrm{df}$ & Mean Square & $\mathrm{F}$ & Sig \\
\hline Btween Groups & 449.612 & 2 & 224.806 & & \\
Within Groups & 452.960 & 67 & 6.761 & 33.252 & .000 \\
Total & 902.571 & 69 & & \\
\hline
\end{tabular}

Table 4 indicate that there was significant difference $(F=33.252, P=.000)$ in the posttest academic performance mean scores between the experimental groups (Co Op-Co Op), (Think-Pair-Share) and control group. By this finding the null hypothesis was rejected and the alternative hypothesis was accepted. However, to find the difference between the experimental groups and control group the researcher used Scheffe test as shown in table 5. 
Table 5: Scheffe test between the experimental groups and control group for the posttest

\begin{tabular}{|l|c|c|c|}
\hline Groups & Mean Difference & Std. Error & Sig \\
\hline Co Op- Co Op Think-Pair-Share & 1.62250 & .83244 & .158 \\
Traditional Method & $5.62897^{\star}$ & .70961 & .000 \\
Think- Pair-Share Traditional Method & $4.00647^{\star}$ & .80973 & .000 \\
\hline
\end{tabular}

Table 5 indicate that there was significant difference between experimental group (Co Op-Co Op) and control group (traditional method) mean difference $\left(5.62897^{*}\right)(P=.000)$, and significant difference between experimental group (ThinkPair-Share) and control group (traditional method) mean difference $\left(4.00647^{*}\right)(P=.000)$. Whilst, , there was no difference between the experimental groups (Co Op-Co Op) and (Think-Pair-Share) mean difference $(1.62250, \mathrm{P}=.158)$

H03: There is no significant difference in the posttest academic performance mean scores of students from different level of study (second and fourth year).

To answer hypothesis 3 the resercher used independent sample t-test to find the difference between posttest academic performance attributed to the level of study (second and fourth year).

Table 6: Descriptive of posttest academic performance mean scores from different level of study

\begin{tabular}{|c|c|c|c|c|c|}
\hline & Level of study & $\mathrm{N}$ & Mean & Std. Deviation & Std. Error Mean \\
\hline Posttest & Second & 40 & 22.950 & 2.374 & .375 \\
\hline & Fourth & 30 & 18.066 & 3.073 & .561 \\
\hline
\end{tabular}

Table 6 revealed that (40) second year students had posttest performance mean scores of (22.950) and standard deviation of (2.374). while (30) fourth year students had posttest performance mean scores of (18.066) and standard deviation of (3.073). However, to find the difference between second and fourth year students in academic performance the researcher used independent sample test as shown in table 7.

Table 7: Independent sample test

\begin{tabular}{|c|c|c|c|c|}
\hline $\mathrm{T}$ & $\mathrm{df}$ & Mean difference & Std. Error difference & Sig (2-tailed) \\
\hline 7.503 & 68 & 4.88 & .650 & .000 \\
\hline
\end{tabular}

The result revealed in table 7 indicate that there was significant difference in the posttest academic performance mean scores of second and fourth year students $(t=7.503, P=.000)$ after the intervention favor for the second year students. As a result the null hypothesis was rejected and the alternative hypothesis was accepted.

H04: There is no significant difference in the posttest academic performance mean scores of students from different specialization (psychology, special education, and Islamic studies).

To answer hypothesis 4 the researcher used ANOVA to find the differences between students from different specialization (psychology, special education, and islamic studies) and academic performance in the posttest as shown in table 8.

Table 8: Posttest academic performance from different specilaization by ANOVA

\begin{tabular}{|l|c|c|c|c|c|}
\hline & Sum of Squares & df & Mean Square & F & Sig \\
\hline Btween Groups & 33.978 & 2 & 16.989 & & \\
Within Groups & 868.593 & 67 & 12.946 & 1.310 & .277 \\
Total & 902.571 & 69 & & \\
\hline
\end{tabular}

Table 8 indicate that there was no significant difference $(F=1.310, P=.277)$ in the posttest academic performance mean scores between students from different specilaization (psychology, special education, and islamic studies). By this finding the null hypothesis was accepted.

H05: There is no significant difference in the delayed posttest academic performance mean scores of students in educational psychology course.

To answer hypothesis 5 the researcher used one way ANOVA for the delayed posttest and scheffe test to find the 
difference between the experimental groups and control group as shown in table (9 and 10).

Table 9: delayedposttest academic performance between experimental groups and control group by ANOVA

\begin{tabular}{|l|c|c|c|c|c|}
\hline & Sum of Squares & df & Mean Square & $F$ & Sig \\
\hline Btween Groups & 113.124 & 2 & & & \\
Within Groups & 432.819 & 67 & 56.562 & 6.460 & .000 \\
Total & 545.943 & 69 & & & \\
\hline
\end{tabular}

Table 9 indicate that there was significant difference $(F=6.460, P=.000)$ in the delayed posttest academic performance mean scores between the study groups. By this finding the null hypothesis was rejected and the alternative hypothesis was accepted. However, to find the difference between the experimental groups and control group the researcher used Scheffe test as shown in table 9.

Table 10: Scheffe test between the experimental groups and control group for the delayed posttest

\begin{tabular}{|l|c|c|c|}
\hline Groups & Mean Difference & Std. Error & Sig \\
\hline Co Op- Co Op Think-Pair-Share & .05750 & .81372 & .998 \\
Traditional Method & $2.60276^{*}$ & .69366 & .002 \\
Think- Pair-Share Traditional Method & $2.54526^{*}$ & .79152 & .008 \\
\hline
\end{tabular}

Table 10 indicate that there was significant difference between experimental group (Co Op-Co Op) and control group (traditional method) on the delayed posttest mean difference $\left(2.60276^{*}, P=.002\right)$, and significant difference between experimental group (Think-Pair-Share) and control group (traditional method) mean difference $\left(2.54526^{*}, \mathrm{P}=.008\right)$. Whereas, there was no difference between the experimental groups (Co Op-Co Op) and (Think-Pair-Share) mean difference $(.05750, P=.998)$.

\section{Discussion}

The present quasi-experimental quantitative study was designed to investigate the outcome of the use of cooperative learning strategies (Co Op- Co Op and Think-Pair-Share) as compared to traditional teaching strategy and the effects of these strategies on academic performance in undergraduate educational psychology course.

One of the findings in this study is that the students taught using cooperative learning strategy (Co Op- Co Op and Think-Pair-Share) had mean gain scores significantly different from those students taught using traditional strategy. The finding revealed that students' performance was better enhanced when students were taught using cooperative learning strategy. This reuslt is in a close agrreement with (Christian and Pepple 2012; Sahin's, 2010; Hwang et al. 2005; Queen, 2009; Gocer, 2010; Adeyemi's,2008) who reported that cooperative learning strategies improve students academic performance scores than students taught via traditional method.

Another finding of this study is that the second year students had mean gain scores in the posttest significantly different from fourth year students'. However, the transitional period from the perparatory year might be responsible for this result. Thus, second year students coming from the preparatory year and they are eager to achive the best grades possible in the courses that will help them to place a root of their GPA for the coming tough years during their study journey compare with fourth year students whom already have stable GPA in their last semester at university and they are prepare themselves to leave. On the other hand, The transitional period following perparatory year graduation and extending to enrollment in the first semester of University is important. Goal achievement, time management, and personal skills were necessary to student's success in the first semester of University.

One more findings in this study revealed that no difference on academic performnce in educational psychology course attributed to students specialization (psychology, special education and islamic studies). This result could be due to that most of the students study at faculty of education coming from the literary sections in their Secondary study and the sample of the present study does not include students from other scientific sections.

One important findings in this study revealed that students taught using cooperative learning strategies (Co OpCo Op and Think-Pair-Share) had mean gain scores significantly different from those students taught using traditional strategy in the delyead posttest which lead to the fact that using such strategies in teaching undergraduate students at university enhanced the memorization of the students' and learning strategies can become memorizing strategies as 
instructors' want students to learn and to be able to organize, store, and retrieve knowledge skills by applying what they know about how the brain learns, store and remembers. Therefore, memory and learning requires the presence of each others, without the accumulation of experience, processing and retention can not be there to learn, and without learning stops the flow of information through various channels of communication. This result is in a close agreement with (Andersen, et al, 2004; Singhal, 2001 ; Dennis, 2002) who reported that the factors affect memory retention and retrieval are the same that affect the achievement and acquisition. Also, conditions that facilitate learning are the same that facilitate retention, recall and retrieval levels are the same levels of learning from cognitive point of view.

\section{Conclusion}

Based on the findings it was concluded that there are significant difference effect between cooperative learning strategies (Co Op-Co Op, Think-Pair-Share) and traditional teaching strategy in teaching of educational psychology course at undergraduate students. Moreover, there are significant difference in academic performance between students' attributed to the level of study (second and fourth year) with favor to the second year. In addition to, there are no difference in students' academic performance attributed to different specialization (psychology, educational studies and islamic studies).

However, significant positive effects on students' academic performance was shown using cooperative learning strategies (Co Op-Co Op, Think-Pair-Share) compare with traditional teaching strategy which lead to fact that instructor's can use different models of cooperative learning to prepare students for different academic tasks and life situations. Although undergraduate students are required to work with others on different tasks to help in improving their skills and share knowledge that lead to good academic performance and achieving the course objectives.

One important things, cooperative learning strategies to be correctly implemented in a variety of educational settings and for diverse learners, it is essential for institutions to provide proper training on cooperative learning skills to instructors' (Adams, 2000 ; Siegel, 2005) reported that the use of cooperative learning strategies might have been so successful because teachers had been properly trained, given adequate preparation time, and were provided with appropriate tools for implementing the strategies to create generation of higher-order thinkers, problem solvers and positive social changes.

\section{Recommendations}

Further empirical studies and analysis in the topic could be beneficial for educators to obtain a complete vision of cooperative learning strategies affect undergraduate students performance.

The present study fail to find the difference between students from the same study section because the sample from the same faculty. Further study could invest cooperative learning strategies with different samples to find the difference between students from literary section and scientic sectoin.

Moreover, it is substantial for instructors to adopt new teaching methodologies to improve undergraduate academic performance and to create new learning strategies which is more convenient to undergraduate students.

\section{Acknowledgement}

The author extends his appreciation to the college of education research center, deanship of scientific research, King Saud University for funding this research work.

\section{References}

Adams, S. (2000). Communication: A key to learning. Tap Into Learning, 2(1), 1-8.

Adeyemi, B. A. (2008). Effects of cooperative learning and problem solving strategies on junior secondary school students' achievement in social studies. Electronic Journal of Research in Educational Psychology, 6(3), 691-708.

Andersen , $G$ et.all (2004). The influence of metacognitive skills on learners' memory of information in a hypermedia envviroment". Journal of educational computing research, Vol. 31 , No. 1 pp. 77 - 93.

Christian and Pepple (2012). Cooperative and individualized learning strategies as predictors of students' achievement in secondary school chemistry in Rivers State. J. Vocational Education and Technology. Vol. 9 No. 2.

Creswell, J. W. (2003). Research design: Qualitative, quantitative, and mixed methods approaches. Thousand Oaks, CA: Corwin.

Damon, W. (1984). Peer education: The untapped potential. Journal of Applied Developmental Psychology, 5, 331-343. 
Daniels, D. H., \& Perry, K. E. (2003). Learner centered according to children. Theory Into Practice, 42(2), 1-9.

Dennis , M (2002). Understanding reading comprehension strategies. http://brom Well.dpsk12.org/stories/story/

Ediger, M. (2001). Learning opportunities in the higher education curriculum. College Student Journal, 35(3), 410.

Felder, R. (1992). How about a quick one?. Chemical Engineering Education, 26(1), $18-19$.

Fink, L.D. (2004). Beyond small groups: Harnessing the extraordinary power of learning. In Michaelsen L., Knight, A. \& Fink L.D. TeamBased Learning: A transformative use of small groups. Sterling, VA: Stylus Publishing.

Ghazi, G. (2003). Effects of the learning together model of cooperative learning on English as a Foreign Language reading achievement, academic self-esteem, and feelings of School alienation. Bilingual Research Journal, 27(3), 451-469.

Gocer, A. (2010). A comparative research on the effectivity of cooperative learning method and jigsaw technique on teaching literary genres. Educational Research and Reviews, 5(8), 439-445.

Hwang, N.R., Lui, G., \& Tong, M.Y.J. (2005). An empirical test of cooperative learning in a passive learning environment. Issues in Accounting Education, 20(2), 151-165.

Jackson, S. L. (2011). Research Method: A modular approach (2nd edition). Wadsworth/ Cengage Learning. Canada. Nelson Education Ltd.

Johnson, D.W., Johnson, R.T., Holubec, E.J. (1986). Circles of learning: Cooperation in the classroom. Edina, MN: Interaction Book Company.

Johnson, D.W., Johnson, R.T., \& Smith K. (1998). Cooperative Learning Returns To College: What Evidence Is There That It Works?, Change, 27-35.

Kagan, S. (1985). Co-op Co-op: A flexible cooperative learning technique. In R. E. Slavin, S. Sharan, S. Kagan, R. Hertz-Lazarowitz, C. Webb, and R. Schmuck (Eds.). Learning to cooperate: Cooperating to learn. New York: Plenum.

Kagan, S. (1989). The structural approach to cooperative learning. Educational Leadership, 47(4), 12-16.

Kimberly, T., Liesl, S.C., Deborah, A. (2003). Approaches to cell biology teaching: cooperative Learning in the science classroom: beyond students working in groups. Cell Biology Education: A Journal of Life Science Education, 2, 1-5.

McMillan, J. H., \& Schumacher, S. (2006). Research in education: Evidence-Based Inquiry. New York. Pearson Education, Inc.

Murry, J. P. \& Murry, J. I. (1992). How do I lecture thee?. College Teaching, 40(3), 109- 113.

Oludipe, D. (2012). Gender Difference in Nigerian Junior Secondary Students' Academic Achievement in Basic Science. Journal of Educational and Social Research, Vol. 2 (1).

Palincsar, A. S., \& Herrenkol, L. R. (2002). Designing collaborative learning contexts. Theory Into Practice, 41(1), 1-9.

Paulson, D.R., \& Faust, J.L. (2008). Active Learning for the College Classroom. Retrieved July 15, 2008 from http://www.calstatela. edu/dept/chem/chem2/Active/main.htm

Rosini, B.A., Jim, F. (1997). The effect of cooperative learning methods on achievement, retention, and attitudes of home economics students in North Carolina. Journal of Vocational and Technical Education. 13(2), 1-7.

Sahin, A. (2010). Effects of jigsaw II technique on academic achievement and attitudes to written expression course. Educational Research and Reviews, 5(12), 777-787.

Siegel, C. (2005). Implementing a research-based model of cooperative learning. The Journal of Educational Research, 98(6), 339-349.

Singhal , M ( 2001)" Reading proficience, reading strategies , metacognitive awarness and L2 readers" . The reading matrix journal, Vol . 1 , No . 1 pp 46-62.

Slavin, R. E. (1996). Cooperative learning in middle and secondary schools. Clearing House, 0009-8655, 69(4), 200.

Slavin, R.E. (1987). Developmental and motivational perspectives on cooperative learning: reconciliation. Child Development, 58, 11611167.

Slavin, R.E. (1990). Cooperative learning: Theory, research, and practice. New Jersey: Prentice Hall.

Queen, susan (2009). The Effect of Cooperative Learning and Traditional Strategies on Academic Performance in Middle School Language Arts. (unpublished doctoral thesis), Walden University

Weimer, M. (2008). Active Learning Advocates and Lectures. Retrieved July 18, 2008 from http://teachingprofessor.blogspot.com/2008/ 06/ active-learning-advocates-andlectures. Html 